\title{
Distribution of Pathotypes with Regard to Host Cultivars in French Wheat Leaf Rust Populations
}

\author{
Henriette Goyeau, Robert Park, Brigitte Schaeffer, and Christian Lannou
}

First and fourth authors: INRA, Laboratoire de Pathologie Végétale, BP 01, 78850 Thiverval-Grignon, France; second author: University of Sydney, Plant Breeding Institute, Camden NSW, Australia; and third author: Unité de recherche Mathématiques et Informatique Appliquées INRA Domaine de Vilvert 78352 Jouy-en-Josas Cedex, France.

Accepted for publication 15 October 2005.

\begin{abstract}
Goyeau, H., Park, R., Schaeffer, B., and Lannou, C. 2006. Distribution of pathotypes with regard to host cultivars in French wheat leaf rust populations. Phytopathology 96:264-273.

Isolates of wheat leaf rust collected from durum and bread wheat cultivars in France during 1999-2002 were analyzed for virulence on 18 Thatcher lines with single genes for leaf rust resistance ( $L r$ genes). Sampling focused on the five most widely grown bread wheat cultivars (two susceptible and three resistant) to allow statistical comparison of diversity indexes between the cultivars. Leaf rust populations from durum and bread wheats were different. The diversity of the bread wheat leaf rust pathotypes, as measured by the Shannon index, ranged from 2.43 to 2.76 over the 4 years. Diversity for wheat leaf rust resistance was limited in the host since we postulated only seven seedling resistance genes in the 35

cultivars most widely grown during 1999-2002. Leaf rust populations were strongly differentiated for virulence within bread wheat cultivars, and diversity was higher on those that were resistant, mainly due to a more even distribution of virulence phenotypes than on susceptible cultivars. The pathogen population on the susceptible cv. Soissons was largely dominated by a single pathotype (073100), whereas all other pathotypes virulent on cv. Soissons either decreased in frequency or remained at a low frequency during the period studied. Several pathotypes including the most complex one were found only on resistant cultivars, even though most of them were virulent on the susceptible cv. Soissons. Specific interactions were necessary, but not always sufficient, to account for pathotype distribution and frequencies on the cultivars, suggesting that selection for virulence to host resistance genes is balanced by other selective forces including selection for aggressiveness.
\end{abstract}

Wheat leaf rust, caused by Puccinia triticina Eriks, was among the most damaging foliar diseases of wheat in Europe at the end of the 20th century. Damaging disease levels have been noted regularly in western Europe (except the UK), Italy, and eastern and southeastern Europe (namely Yugoslavia and Romania) (25). During the last 30 years, particularly in western European countries, fungicides have been used to control diseases including leaf rust in most years (25). Although selection for resistance to leaf rust has remained an issue for wheat breeders, it has not been a top priority. This probably explains the limited studies on this pathosystem in Europe as compared with other regions like North America $(12,14,20)$ and Australia (27). Pathogen populations have been monitored and host resistance genes postulated from 1966 to 1993 in the Czech Republic (4). A more recent study by Mesterhazy et al. (23) that attempted to coordinate a 4-year survey of $P$. triticina in western, southern, and eastern Europe showed a great variation in the distribution of virulence phenotypes between years and countries. However, no interpretation of the observed diversity could be provided because of a lack of knowledge of the host resistance genes used in these countries. Park et al. (29) postulated leaf rust resistance genes in western European wheat cultivars grown in 1995, and related this to a survey of $P$. triticina populations in the same year. In this study, it was noted that western Europe comprised different epidemiological units, with different climates and different host populations, and that the role of host selection on the pathogen was diffi-

Corresponding author: H. Goyeau; E-mail address: goyeau @ grignon.inra.fr

DOI: 10.1094/PHYTO-96-0264

This article is in the public domain and not copyrightable. It may be freely reprinted with customary crediting of the source. The American Phytopathological Society, 2006. cult to estimate because virulence on the genes with the highest frequencies in the host population, Lrl3 and Lrl4a, had not been monitored. Moreover, this study was limited to 1 year. The necessity to place the results of population studies in a perspective of several years was stressed by Brown (5).

In this paper, we describe a 4-year study of host and pathogen populations in which we placed special emphasis on selection by the host. To characterize host selection as accurately as possible, the sampling scheme was designed to collect leaf rust isolates from identified cultivars, providing more information than what would be gained from pooling results from many different cultivars (36). The pathogen population was characterized through two complementary approaches: (i) a classical survey of virulences on durum wheat cultivars and minor bread wheat cultivars to provide a broad view of virulences in $P$. triticina populations in France; and (ii) a detailed sampling on the five main bread wheat cultivars. We focused our sampling on the most widely grown cultivars, whether resistant or susceptible, to obtain sample sizes large enough to be considered representative of the population present on each of these cultivars. The study was limited at the spatial scale to one country, France, assuming that it could be regarded as a single epidemiogical unit to overcome the above-mentioned difficulties of heterogeneity at the continental scale.

\section{MATERIALS AND METHODS}

Sampling. Because $98 \%$ of wheat fields in France are sprayed with fungicides (3), samples were collected from a network of unsprayed nurseries planted annually in approximately 50 different locations throughout the wheat-growing area by breeders (the French Wheat Breeders group 'Club des Cinq') or extension services (Arvalis-Institut du Végétal). For bread wheat, the sampling effort focused on the most widely grown cultivars (Table 1) 
planted as checks in all nurseries, i.e., Soissons, Isengrain, and Trémie from 1999 to 2002, and Apache and Orvantis from 2001 to 2002. On each site and for each cultivar, a few infected leaves were collected during May or June (a single collection date per location) from small plots (10 to $20 \mathrm{~m}^{2}$ ) from which one singlepustule isolate was selected and increased, giving one isolate per cultivar and location. In addition, in the same nurseries, we collected leaf rust samples from minor bread and durum wheat cultivars. Since the minor cultivars were not present in each location, the sample size for each minor cultivar was less than 10 .

The different populations considered were (i) the population $P_{d}$ growing on durum wheat cultivars; (ii) the population $\mathrm{P}_{\mathrm{b}}$ growing on all bread wheat cultivars, including five major and several minor cultivars; and (iii) the five populations $\left(\mathrm{P}_{1}\right.$ to $\left.\mathrm{P}_{5}\right)$ growing on the five major bread wheat cultivars, $P_{1}$ to $P_{5}$ being subpopulations of $\mathrm{P}_{\mathrm{b}}$. Selection by host could thus be evaluated for the influence of host species by comparing $\mathrm{P}_{\mathrm{d}}$ and $\mathrm{P}_{\mathrm{b}}$ and the influence of resistance genes within the bread wheat species by comparing no matter what given population (from $\mathrm{P}_{1}$ to $\mathrm{P}_{5}$ ), to another. Moreover, $\mathrm{P}_{\mathrm{b}}$ allowed a comparison of our results with the published data on populations of $P$. triticina in other countries, where the cultivar is not taken into account in the sampling scheme. The sample from $\mathrm{P}_{\mathrm{d}}$ was collected in 1999, 2000, and 2001 from 8, 7, and 16 cultivars, respectively, yielding 19, 16, and 47 isolates, respectively, with a total of 82 isolates for the 3 years. A minimum sample size of 50 was achieved on cvs. Soissons $\left(\mathrm{P}_{1}\right)$ and Isengrain $\left(\mathrm{P}_{2}\right)$, whereas collections from resistant cultivars (Trémie, Apache, and Orvantis, $\mathrm{P}_{3}, \mathrm{P}_{4}$, and $\mathrm{P}_{5}$, respectively) were more limited and yielded a sample size from 18 to 55 depending on the year (Table 2). The sample from $\mathrm{P}_{\mathrm{b}}$ was obtained from 18 different bread wheat cultivars in 1999 and 2000, 13 cultivars in 2001, and 21 cultivars in 2002, yielding a sample size from 168 to 234 depending on the year (Table 2) with a total of 821 isolates for the 4 years.

Pathotype determination. Prior to inoculation, all healthy material was grown in air-filtered cabinets in a glasshouse at temperatures between 15 and $25^{\circ} \mathrm{C}$ and with a 14-h photoperiod (daylight supplemented by $400 \mathrm{~W}$ Na-lamps).
Infected field-collected leaves were wiped gently on 7-day-old seedlings of the wheat cv. Michigan Amber that had been treated with $20 \mathrm{ml}$ of a maleic hydrazide solution $(0.25 \mathrm{~g}$ of maleic hydrazide per liter of $\mathrm{H}_{2} \mathrm{O}$ ) to prevent emergence of secondary leaves and increase the size of uredinia. Inoculated seedlings were placed for $24 \mathrm{~h}$ in a dew chamber at $15^{\circ} \mathrm{C}$, then in the glasshouse. One week after inoculation, the seedlings were trimmed so that only one plant with one uredinium remained in each pot. Cellophane bags were then placed on the pots to prevent contamination between isolates. Spores from a single uredinium were collected with a cyclone collector into a 00 gelatin capsule. Spores were increased by adding $0.5 \mathrm{ml}$ of light mineral oil to each capsule and spraying the resulting spore suspension onto 7-day-old Michigan Amber seedlings. The spores collected 10 days after inoculation were divided into two batches, one to inoculate a differential set and one for storage at $-80^{\circ} \mathrm{C}$. The differential sets were sown in pressed-peat pots $\left(3 \times 3 \mathrm{~cm}^{2}\right)$ containing a commercial compost (peat substrate; Gebr. Brill Substrate, Georgsdorf, Germany) with four seedlings per pot and two pots per line (eight seedlings for each differential line). The differential set comprised 17 Thatcher differentials, $\operatorname{Lr} 1, \operatorname{Lr} 2 a, \operatorname{Lr} 2 b$, Lr2c, Lr3a, Lr3bg, Lr3ka, Lr10, Lr13, Lr14a, Lr15, Lr16, Lr17, Lr20, Lr23, Lr26, Lr37, the Australian cv. Harrier carrying Lr17b (32) and the susceptible check cv. Morocco. After inoculation with a spore suspension, the sets were placed in a dew chamber for $24 \mathrm{~h}$ at $15^{\circ} \mathrm{C}$ and then for 9 days in a growth chamber maintained at $22^{\circ} \mathrm{C}$ with a 16 -h photoperiod given by metal halide lamps $(350 \mu \mathrm{E})$. Infection types on the differentials were read 10 days after inoculation according to Stakman et al. (35). Each isolate was assigned a six-digit code adapted from the system described by Gilmour (7): the 18 differential isolines were arranged in six sets of three to assign to each isolate an octal pathotype code.

Postulation of resistance genes. All cultivars belonging to the list of the 10 most widely grown cultivars in France, in any of the years 1990-2002, were analyzed to determine which leaf rust resistance genes were present. Nine of these cultivars were tested at the Plant Breeding Institute, The University of Sydney, Austra-

TABLE 1. Percentage of wheat area planted to five cultivars in France during 1999-2002a

\begin{tabular}{|c|c|c|c|c|c|c|}
\hline Cultivar & Registration year & Pedigree & 1999 & 2000 & 2001 & 2002 \\
\hline Soissons $(\operatorname{Lr} 14 a)$ & 1988 & Hybride naturel dans $35 /$ Iena & 15 & 11 & 11 & 9 \\
\hline Isengrain ( $\mathrm{Lr} 14 \mathrm{a})$ & 1997 & Apollo/Soissons & 8 & 11 & 14 & 14 \\
\hline Trémie $(\operatorname{Lr} 10, \operatorname{Lr} 13)$ & 1992 & SE32/Moulin & 11 & 8 & 6 & 4 \\
\hline Apache $(\operatorname{Lr} 13, L r 37)$ & 1998 & Axial/NRPB 84-4233 & - & - & 8 & 17 \\
\hline Orvantis $(\operatorname{Lr} 10, \operatorname{Lr} 13, \operatorname{Lr} 37)$ & 1999 & Thésée/Disponent/Monopol/3${ }^{3}$ Torfrida & - & - & - & 4 \\
\hline
\end{tabular}

a The percentage of the most commonly grown cultivar for each year is given in bold.

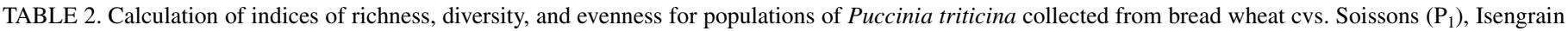
$\left(\mathrm{P}_{2}\right)$, Trémie $\left(\mathrm{P}_{3}\right)$, Apache $\left(\mathrm{P}_{4}\right)$, and Orvantis $\left(\mathrm{P}_{5}\right)$ during 1999-2002

\begin{tabular}{|c|c|c|c|c|c|c|c|c|c|c|c|c|c|c|c|c|c|c|c|c|}
\hline \multirow[b]{2}{*}{ Statistic } & \multicolumn{4}{|c|}{$1999^{\mathrm{a}}$} & \multicolumn{4}{|c|}{$2000^{\mathrm{a}}$} & \multicolumn{6}{|c|}{2001} & \multicolumn{6}{|c|}{2002} \\
\hline & $\mathrm{P}_{1}$ & $\mathrm{P}_{2}$ & $\mathrm{P}_{3}$ & $\mathrm{P}_{\mathrm{b}}{ }^{\mathrm{b}}$ & $\mathrm{P}_{1}$ & $\mathrm{P}_{2}$ & $\mathrm{P}_{3}$ & $\mathrm{P}_{\mathrm{b}}$ & $\mathrm{P}_{1}$ & $\mathrm{P}_{2}$ & $\mathrm{P}_{3}$ & $\mathrm{P}_{4}$ & $\mathrm{P}_{5}$ & $\mathrm{P}_{\mathrm{b}}$ & $\mathrm{P}_{1}$ & $\mathrm{P}_{2}$ & $\mathrm{P}_{3}$ & $\mathrm{P}_{4}$ & $\mathrm{P}_{5}$ & $\mathrm{P}_{\mathrm{b}}$ \\
\hline Sample size & 53 & 48 & 32 & 168 & 57 & 50 & 36 & 187 & 63 & 61 & 55 & 19 & 18 & 234 & 47 & 52 & 20 & 31 & 24 & 231 \\
\hline Richness & 16 & 17 & 9 & 35 & 12 & 20 & 16 & 45 & 13 & 11 & 14 & 12 & 10 & 34 & 11 & 13 & 11 & 14 & 12 & 42 \\
\hline$H^{\prime}$ & 2.354 & 2.170 & 1.749 & 2.763 & 1.533 & 2.021 & 2.554 & 2.691 & 1.556 & 1.181 & 2.313 & $\underline{2.351^{\mathrm{c}}}$ & 2.033 & 2.430 & 1.561 & 1.627 & 2.151 & 2.434 & 2.200 & 2.677 \\
\hline $\begin{array}{l}\text { Confidence } \\
\text { interval }^{\mathrm{d}}\end{array}$ & $\begin{array}{l}2.25- \\
2.60\end{array}$ & $\begin{array}{l}2.03- \\
2.51\end{array}$ & $\begin{array}{l}1.58 \\
2.07\end{array}$ & $\begin{array}{l}2.70- \\
2.94\end{array}$ & $\begin{array}{l}1.30- \\
1.90\end{array}$ & $\begin{array}{l}1.81- \\
2.67\end{array}$ & $\begin{array}{l}2.55- \\
2.65\end{array}$ & $\begin{array}{l}2.60- \\
2.90\end{array}$ & $\begin{array}{l}1.30- \\
1.97\end{array}$ & $\begin{array}{l}0.91- \\
1.59\end{array}$ & $\begin{array}{l}2.24- \\
2.47\end{array}$ & $\underline{\underline{2.40-}}$ & $\begin{array}{l}1.95- \\
2.22\end{array}$ & $\begin{array}{l}2.31- \\
2.67\end{array}$ & $\begin{array}{l}1.32- \\
1.93\end{array}$ & $\begin{array}{l}1.35- \\
2.11\end{array}$ & $\begin{array}{l}2.11- \\
2.32\end{array}$ & $\begin{array}{l}2.43- \\
2.51\end{array}$ & $\begin{array}{l}2.15- \\
2.37\end{array}$ & $\begin{array}{l}2.60- \\
2.90\end{array}$ \\
\hline N1 & 10.526 & 8.762 & 5.748 & 15.843 & 4.631 & 7.549 & 12.855 & 14.752 & 4.740 & 3.258 & 10.108 & 10.497 & 7.637 & 11.360 & 4.763 & 5.091 & 8.596 & 11.403 & 9.023 & 14.538 \\
\hline $\mathrm{G}$ & 7.184 & 5.333 & 4.531 & 9.834 & 2.592 & 3.289 & 10.623 & 5.533 & 2.507 & 1.880 & 8.198 & 9.256 & 5.786 & 5.072 & 2.910 & 2.683 & 6.897 & 9.707 & 7.024 & 7.860 \\
\hline $\begin{array}{l}\text { Evenness } \\
(E 5)\end{array}$ & 0.649 & 0.558 & 0.744 & 0.595 & 0.438 & $\underline{0.350}^{\mathrm{c}}$ & 0.812 & 0.330 & 0.403 & 0.390 & 0.790 & 0.869 & 0.721 & 0.393 & 0.508 & 0.411 & 0.776 & 0.837 & 0.751 & 0.507 \\
\hline $\begin{array}{l}\text { Confidence } \\
\text { interval }^{\mathrm{d}}\end{array}$ & $\begin{array}{l}0.52- \\
0.73\end{array}$ & $\begin{array}{l}0.40- \\
0.57\end{array}$ & $\begin{array}{l}0.56- \\
0.81\end{array}$ & $\begin{array}{l}0.52- \\
0.62\end{array}$ & $\begin{array}{l}0.37- \\
0.47\end{array}$ & $\underline{0.33-}$ & $\begin{array}{l}0.66- \\
0.89\end{array}$ & $\begin{array}{l}0.29- \\
0.34\end{array}$ & $\begin{array}{l}0.35- \\
0.42\end{array}$ & $\begin{array}{l}0.35- \\
0.40\end{array}$ & $\begin{array}{l}0.64- \\
0.87\end{array}$ & $\begin{array}{l}0.74- \\
0.96\end{array}$ & $\begin{array}{l}0.48- \\
0.83\end{array}$ & $\begin{array}{l}0.34- \\
0.42\end{array}$ & $\begin{array}{l}0.40- \\
0.57\end{array}$ & $\begin{array}{l}0.36- \\
0.42\end{array}$ & $\begin{array}{l}0.56- \\
0.86\end{array}$ & $\begin{array}{l}0.71- \\
0.92\end{array}$ & $\begin{array}{l}0.51- \\
0.84\end{array}$ & $\begin{array}{l}0.43- \\
0.54\end{array}$ \\
\hline
\end{tabular}

${ }^{\text {a }} \mathrm{P}_{4}$ and $\mathrm{P}_{5}$ could not be sampled in 1999 and 2000 because cvs. Apache and Orvantis, recently registered, were not present in the nurseries.

${ }^{\mathrm{b}} \mathrm{P}_{\mathrm{b}}$ indices were calculated from a sample including isolates from all bread wheat cultivars (minor cultivars and five major cultivars).

c The underlined values, calculated from the observed sample, were not included in the confidence interval calculated with the BCa method.

d Confidence intervals were calculated by the bootstrapping approach (BCa method) by Grünwald et al. (8). 
lia, following the procedure described by Park et al. (29). For the remaining cultivars, multipathotype tests were conducted in a growth room under the conditions described above for pathotype determination. A selection of 15 pathotypes of $P$. triticina was used (Table 3). Spore suspension (3 $\mathrm{mg}$ of spores per $\mathrm{ml}$ of mineral oil) was sprayed on the first leaves of 12 seedlings of each cultivar using $0.7 \mathrm{ml}$ per tray of 240 seedlings. A set of differential cultivars was included in each test to check the identity and purity of the isolate as well as the infection type. Infection types were scored according to Stakman et al. (35).

Data analysis. Diversity for virulence phenotypes in the populations was estimated by the Shannon index

$$
H^{\prime}=-\sum p_{i} \ln \left(p_{i}\right)
$$

in which $p_{i}$ is the frequency of the $i$ th phenotype. Since differences in an index of diversity can reflect variation in richness (i.e., the number of genotypes observed), evenness (i.e., the distribution of the genotypes), or both, we have calculated these indices and computed means and confidence intervals whenever possible. Richness was evaluated by the number of phenotypes, and evenness evaluated by the index $E_{5}$ proposed by Grünwald et al. (9):

$$
E_{5}=(G-1) /\left(N_{1}-1\right)
$$

in which $G$ is the Stoddart and Taylor index, $G=1 / \Sigma p_{i}{ }^{2}$, and $N_{1}=e^{H^{\prime}}$.

We used the bootstrapping approach recommended by Grünwald et al. (9) to obtain confidence intervals on the diversity index $H^{\prime}$ (Shannon index) and evenness index $E_{5}$, using the $\mathrm{BCa}$ (accelerated bootstrap procedure) with the ' $R$ ' software ( $R$ Development Core Team (2004). $\mathrm{R}$ is a language and environment for statistical computing. ( $\mathrm{R}$ Foundation for Statistical Computing, Vienna, Austria; ISBN 3-900051-07-0, http://www.Rproject.org). However, in our calculations, this method twice yielded a confidence interval that did not include the population mean. In these two cases (underlined in Table 2), the ratio of richness to sample size was very high. Because the theory is based on asymptotic approximation, our sample size might have been too small in these two cases.

Index $N_{1}=e^{H^{\prime}}$ represents the number of equally common genotypes that would produce the same diversity as $H^{\prime}$. Because $G$ weighs the number of abundant genotypes more strongly and $N_{1}$ weighs rarer genotypes more strongly (9), different rankings of the populations were obtained in some cases depending whether $H^{\prime}\left(\right.$ and $\left.N_{1}\right)$, or $G$ were considered.

Calculation of a diversity index was performed for the bread wheat populations $\mathrm{P}_{1}$ to $\mathrm{P}_{5}$ and $\mathrm{P}_{\mathrm{b}}$, but not for the durum wheat population $\mathrm{P}_{\mathrm{d}}$ because of the small sample size.

\section{RESULTS}

Comparison of $\mathbf{P}_{\mathbf{d}}$ and $\mathbf{P}_{\mathbf{b}}$. In the durum wheat population $\mathrm{P}_{\mathrm{d}}$, a total of 16 pathotypes was identified (Table 4), of which seven were found very rarely (only once a year in the samples) or not at all on bread wheat. The most frequent pathotype was 012020 , virulent on three genes only $(\operatorname{Lr} 2 c, \operatorname{Lr} 10$, and $L r 20)$, whereas this pathotype was identified only three times in $\mathrm{P}_{\mathrm{b}}$ (Table 5). In the bread wheat population $\mathrm{P}_{\mathrm{b}}$, a total 104 pathotypes was identified (Table 5), with 34 to 45 different pathotypes identified each year, of which 16 to 25 were found only once in the sample. The proportion of these pathotypes found only once in the year was roughly constant, from 47 to $60 \%$ across the 4 years. Virulence frequencies on Lr13, Lr14a, Lr16, and Lr20 (Table 6) were significantly different between durum wheat and bread wheat.

Pathotype distribution on the five major wheat cultivars. On the two susceptible cvs. Soissons and Isengrain, disease level was high ( 80 on the modified Cobb scale; 30 ) in the 4 years the day samples were collected. In contrast, there was at most, one pustule per flag leaf on cvs. Trémie ( $\mathrm{LrlO}$ and Lrl3) and Orvantis (Lr10, Lr13, and Lr37) in some years, and the maximum disease level on these cultivars was between 1 and 5. Cv. Apache was more variable in its leaf rust response with a disease level usually between 1 and 10, but reaching 50 at one location in 2002 .

The distribution of the pathotypes in the populations $\mathrm{P}_{1}$ to $\mathrm{P}_{5}$ is plotted in Figure 1. Pathotypes found only once at most in each year were pooled in a group named "rare". As soon as a pathotype was found at least twice in 1 year, it was plotted individually. Because the distributions on cvs. Soissons and Isengrain were rather similar, the first nine pathotypes on the $x$ axis are the same for these two cultivars. There were two dominant pathotypes in 1999: (i) pathotype 073100 (virulent on Lr2c, Lr3a, Lr3bg, $L r 3 k a, L r 10$, and LrI $4 a$; frequency 28 and 33\%); and (ii) pathotype 014103 (virulent on $L r 2 c, L r 13, L r 14 a, L r 26$, and $L r 17 b$; frequency 19 and 25\%) for cvs. Soissons and Isengrain, respectively. The frequency of pathotype 014103 decreased over the following years, dropping to 0 in 2002 that resulted in a population dominated by pathotype 073100 that represented 54 to $72 \%$ of the isolates. The population on these two cultivars was also composed of five to nine pathotypes found at low frequencies, between 2 and 13\%, and rare pathotypes found only once, representing 2 to 11 pathotypes each year, i.e., between 5 and $26 \%$ of the population.

All pathotypes found on cvs. Soissons (except pathotype 016404; Fig. 1) and Isengrain (except for four belonging to the group of rare pathotypes) possessed virulence for the gene $\mathrm{Lrl} 4 \mathrm{a}$ postulated in these two cultivars.

\begin{tabular}{|c|c|c|}
\hline Isolate & Pathotype $^{\mathrm{a}}$ & Virulence at the seedling stage ${ }^{b}$ \\
\hline B9405-2B & 075337 & Lr2c, Lr3, Lr3bg, Lr3ka, Lr13, Lr14a, Lr15, Lr17, Lr17b, Lr20, Lr26, Lr37 \\
\hline B9201-2C3 & 014103 & $\operatorname{Lr} 2 c, \operatorname{Lr} 13, \operatorname{Lr} 14 a, \operatorname{Lr} 17 b, \operatorname{Lr} 26$ \\
\hline B9506-2B & 014103 & Lr2c, Lr13, Lr14a, Lr17b, Lr26 \\
\hline B950365 & 073100 & Lr2c, Lr3, Lr3bg, Lr3ka, Lr10, Lr14a \\
\hline B9384-1C1 & 075337 & Lr2c, Lr3, Lr3bg, Lr3ka, Lr13, Lr14a, Lr15, Lr17, Lr17b, Lr20, Lr26, Lr37 \\
\hline B950019-A & 012026 & Lr2c, Lr10, Lr17b, Lr20, Lr37 \\
\hline B950506A & 106232 & Lr1, Lr10, Lr13, Lr15, Lr17, Lr17b, Lr20 \\
\hline $\mathrm{B} 77 \mathrm{SaBa}$ & 775237 & Lr1, Lr2a, Lr2b, Lr2c, Lr3, Lr3bg, Lr3ka, Lr13, Lr15, Lr17, Lr17b, Lr20, Lr26, Lr37 \\
\hline B347 & 777234 & Lr1, Lr2a, Lr2b, Lr2c, Lr3, Lr3bg, Lr3ka, Lr10, Lr13, Lr15, Lr17, Lr20, Lr37 \\
\hline B9834-E & 016504 & $\operatorname{Lr} 2 c, \operatorname{Lr} 10, \operatorname{Lr} 13, \operatorname{Lr} 14 a, \operatorname{Lr} 16, \operatorname{Lr} 37$ \\
\hline B00M057-A & 166336 & $\operatorname{Lr} 1, \operatorname{Lr} 3, \operatorname{Lr} 3 b g, \operatorname{Lr} 10, \operatorname{Lr} 13, \operatorname{Lr} 14 a, \operatorname{Lr} 15, \operatorname{Lr} 17, \operatorname{Lr} 17 b, \operatorname{Lr} 20, \operatorname{Lr} 37, \operatorname{Lr} 27+\operatorname{Lr} 31$ \\
\hline
\end{tabular}

TABLE 3. Standard isolates of Puccinia triticina used in multipathotype tests for postulation of resistance genes

${ }^{a}$ Six-digit code based on a 18-Lr genes differential set (Thatcher lines Lr1, Lr2a, Lr2b, Lr2c, Lr3, Lr3bg, Lr3ka, Lr10, Lr13, Lr14a, Lr15, Lr16, Lr17, Lr20, Lr23, $L r 26$, the Australian cv. Harrier $(\operatorname{Lr} 17 b)$, and $L r 37$.

b Tested for pathogenicity on the 18 lines listed above in addition to the Thatcher lines with the resistance genes $\operatorname{Lr} 9, \operatorname{Lr} 19, \operatorname{Lr} 24, \operatorname{line} \mathrm{CS} 2 \mathrm{~A} / 2 \mathrm{M}(\operatorname{Lr} 28)$, and the Australian cv. Gatcher $(\operatorname{Lr} 10, \operatorname{Lr} 27+\operatorname{Lr} 31)$. 
The population $\mathrm{P}_{3}$ from cv. Trémie was composed of three to four pathotypes with intermediate frequencies of 9 to $31 \%$, then three to seven pathotypes with low frequencies ( 2 to $7 \%$ ), and some rare pathotypes representing 7 to $25 \%$ of the population (Fig. 1). Pathotypes 016404, 016504, and 016206, combining virulences for $\operatorname{LrlO}$ and $\mathrm{Lrl3}$ present in Trémie, were the main components of $\mathrm{P}_{3}$ in 1999 and 2000 . The population then changed with the rapid emergence of a new group of pathotypes. This group included three closely related pathotypes also virulent on LrlO and $\mathrm{Lrl3}$, pathotype 166337 that was found only twice in 2000 and increased to $13 \%$ of $\mathrm{P}_{3}$ in 2001 and pathotypes 166336 (differing from 166337 by avirulence on $\operatorname{Lr} 26$ ) and 166376 (differing from 166336 by virulence on $\operatorname{Lr} 23$ ) representing $16 \%$ and $9 \%$, respectively, of $\mathrm{P}_{3}$ in 2001. This group of three pathotypes accounted for $38 \%$ of $\mathrm{P}_{3}$ in 2001. Pathotypes 166337 and 166376 were not detected in 2002, but pathotype 166336 remained at a frequency of $25 \%$. Pathotype 073100 , although avirulent on $\operatorname{Lr} 13$ (one of the resistance genes of cv. Trémie), was found each year in $\mathrm{P}_{3}$ at frequencies between 3 and $14 \%$. Of the 32 pathotypes found during the 4 years on cv. Trémie, 13 were avirulent either on $\operatorname{LrlO}$ (four pathotypes) or Lrl3 (eight pathotypes) or on both genes (one pathotype).

The distribution of pathotypes was more balanced on $\mathrm{cv}$. Apache (Lrl3 and Lr37), with the population comprising eight pathotypes at frequencies between 3 and $16 \%$ and a group of rare pathotypes representing 19 to $26 \%$ of the population. The population on cv. Orvantis (Lr10, Lrl3, and Lr37) comprised the lowest number of pathotypes, with only four pathotypes at frequencies between 6 and 33\% and rare pathotypes representing 33\% of the population. All four pathotypes found on cv. Orvantis were present on Apache. In addition, one found on Apache (pathotype 166336) was also found on Trémie and a second (pathotype 075317 virulent on $L r 2 c, L r 3 a, L r 3 b g, L r 3 k a, L r 13, L r 14 a, L r 15$, $L r 17, L r 26, L r 17 b$, and $L r 37$ at the seedling stage) was not found on any other cultivar. Again, as for Trémie, although pathotype 073100 was avirulent on Lr13, it was present on Apache and Orvantis at a frequency as much as $17 \%$.

Diversity indices. The highest richness index, calculated as the number of phenotypes in the sample, was always obtained on the population $\mathrm{P}_{\mathrm{b}}$ (Table 2). In 1999, the lowest richness was observed on cv. Trémie $\left(\mathrm{P}_{3}\right)$, but in 2000 it was observed on cv. Soissons $\left(\mathrm{P}_{1}\right)$. In 2001 and 2002, richness was almost constant across the cultivars, ranging between 10 and 14 .
Diversity and evenness for each year across cultivars. The diversity index $H^{\prime}$ was higher in population $P_{\mathrm{b}}$ than in populations $\mathrm{P}_{1}$ to $\mathrm{P}_{5}$ for the 4 years and this difference was significant in most cases (12 of 16). For the 4 years, diversity on cv. Soissons was the same as on cv. Isengrain. In 1999, diversity on cv. Trémie was significantly lower than on cvs. Soissons and Isengrain, whereas in 2000, it was higher than on cv. Soissons and the same as on cv. Isengrain. In 2001 and 2002, diversity on the two susceptible cultivars was significantly lower than on the three resistant cvs. Trémie, Apache, and Orvantis.

In 1999, evenness was the same across the cultivars. In 2000, evenness on Trémie was not only higher than on other cultivars, but also on the global population. In 2001, evenness on Soissons, Isengrain, and the global population was significantly lower than on the resistant cvs. Trémie, Apache, and Orvantis. In 2002, the situation was not so clear, differences being significant in only one-half of the cases. Evenness on Isengrain was lower than on any other cultivar except Soissons.

Diversity and evenness for each cultivar across years. In 1999, diversity and evenness on cv. Soissons were higher than in the three other years. Diversity on cv. Isengrain was rather constant across the years, but was lowest in 2001. Some variations in evenness were observed, which was highest in 1999 and lowest in 2000. For cv. Trémie, diversity was lowest in 1999, reached a maximum in 2000, and then decreased in 2001 and 2002, whereas evenness was constant across the 4 years. Diversity and evenness were stable for cvs. Apache and Orvantis between 2001 and 2002. For the population $P_{b}$, diversity was very stable across the years, varying between 2.43 and 2.76, whereas evenness varied, with a maximum (0.595) in 1999, a minimum (0.350) in 2000, and then increased to reach in 2002 the same level (0.507) as in 1999.

Relative importance of the different resistance genes in the host population. Resistance gene $\mathrm{Lrl3}$ was the most commonly detected gene, found in 25 of 35 cultivars analyzed (Table 7) and was also the most widely deployed gene present in average on $40.1 \%$ of the wheat area during 1999-2002. Lr14a, although found in only seven of the cultivars, was similar to $\operatorname{Lr} 13$ by the importance of cultivation ( $35 \%$ of the wheat area) because of the dominance of cv. Soissons ( Lr14a). Fourteen of 35 cultivars examined had either $\operatorname{Lrl3}$ or $\operatorname{Lrl} 4 a$ alone. In addition, resistance genes Lr3, Lr10, Lr20, Lr26, and Lr37 were postulated in the cultivars (Table 7). Three cultivars had no detectable resistance

TABLE 4. Number of isolates of Puccinia triticina collected from durum wheat (population $\mathrm{P}_{\mathrm{d}}$ ) in France in 1999-2001, identified for virulence phenotype on 18 differential hosts

\begin{tabular}{|c|c|c|c|c|c|}
\hline \multirow[b]{2}{*}{ Virulence phenotype $^{\mathrm{a}}$} & \multirow[b]{2}{*}{ Virulences ( $L r$ genes) } & \multicolumn{3}{|c|}{ Year } & \multirow[b]{2}{*}{ Total } \\
\hline & & 1999 & 2000 & 2001 & \\
\hline 012020 & $2 c, 10,20$ & 5 & 6 & 28 & 39 \\
\hline 073100 & $2 c, 3 a, 3 b g, 3 k a, 10,14 a$ & & 6 & 7 & 13 \\
\hline 012062 & $2 c, 10,20,23,17 b$ & 1 & & 8 & 9 \\
\hline 075337 & $2 c, 3 a, 3 b g, 3 k a, 13,14 a, 15,17,20,26,17 b, 37$ & 3 & & & 3 \\
\hline 077317 & $2 c, 3 a, 3 b g, 3 k a, 10,13,14 a, 15,17,26,17 b, 37$ & 2 & & & 2 \\
\hline 012120 & $2 c, 10,14 a, 20$ & & & 2 & 2 \\
\hline 771237 & $1,2 a, 2 b, 2 c, 3 a, 3 b g, 3 k a, 15,17,20,26,17 b, 37$ & 2 & & & 2 \\
\hline 010120 & $2 c, 14 a, 20$ & 2 & & & 2 \\
\hline 012400 & $2 c, 10,16$ & & 2 & & 2 \\
\hline 014103 & $2 c, 13,14 a, 26,17 b$ & 2 & & & 2 \\
\hline 775237 & $1,2 a, 2 b, 2 c, 3 a, 3 b g, 3 k a, 13,15,17,20,26,17 b, 37$ & 1 & & & 1 \\
\hline 071615 & $2 c, 3 a, 3 b g, 3 k a, 15,16,17,26,37$ & 1 & & & 1 \\
\hline 016404 & $2 c, 10,13,16,37$ & & 1 & & 1 \\
\hline 075317 & $2 c, 3 a, 3 b g, 3 k a, 13,14 a, 15,17,26,17 b, 37$ & & & 1 & 1 \\
\hline 012126 & $2 c, 10,14 a, 20,17 b, 37$ & & 1 & & 1 \\
\hline 012122 & $2 c, 10,14 a, 20,17 b$ & & & 1 & 1 \\
\hline Total number of isolates & & 19 & 16 & 47 & 82 \\
\hline Total number of pathotypes & & 9 & 5 & 6 & 16 \\
\hline
\end{tabular}

${ }^{a}$ Six-digit code based on a 18 Lr genes differential set (Thatcher lines Lr1, Lr2a, Lr2b, Lr2c, Lr3, Lr3bg, Lr3ka, Lr10, Lr13, Lr14a, Lr15, Lr16, Lr17, Lr20, Lr23, Lr26, the Australian cv. Harrier $(\operatorname{Lr} 17 b)$, and Lr37. 
gene. Combinations of two resistance genes were postulated for 13 cultivars, and combinations of three resistance genes were postulated for only three cultivars, of which two were registered recently (Orvantis in 2000 and Caphorn in 2001).

\section{DISCUSSION}

Since virtually all commercial wheat fields in France are sprayed with fungicide we had to collect isolates from unsprayed blocks in experimental nurseries. As evaluated with the Shannon index, nursery collections were more diverse than field collections in the prairie area in Canada in 1990 (15), however, based on the Rogers index and contingency table analysis, they were regarded as similar. Although it was stated that nurseries could not accurately reflect the level of diversity occurring in commercial fields (18), it was concluded in a later study (19) that in most areas there were no consistent differences in pathotype diversity between field and nursery collections.

TABLE 5. Number of isolates of Puccinia triticina collected from bread wheat (population $P_{b}$ ) in France during 1999-2002 and identified by virulence phenotype on 18 differential hosts

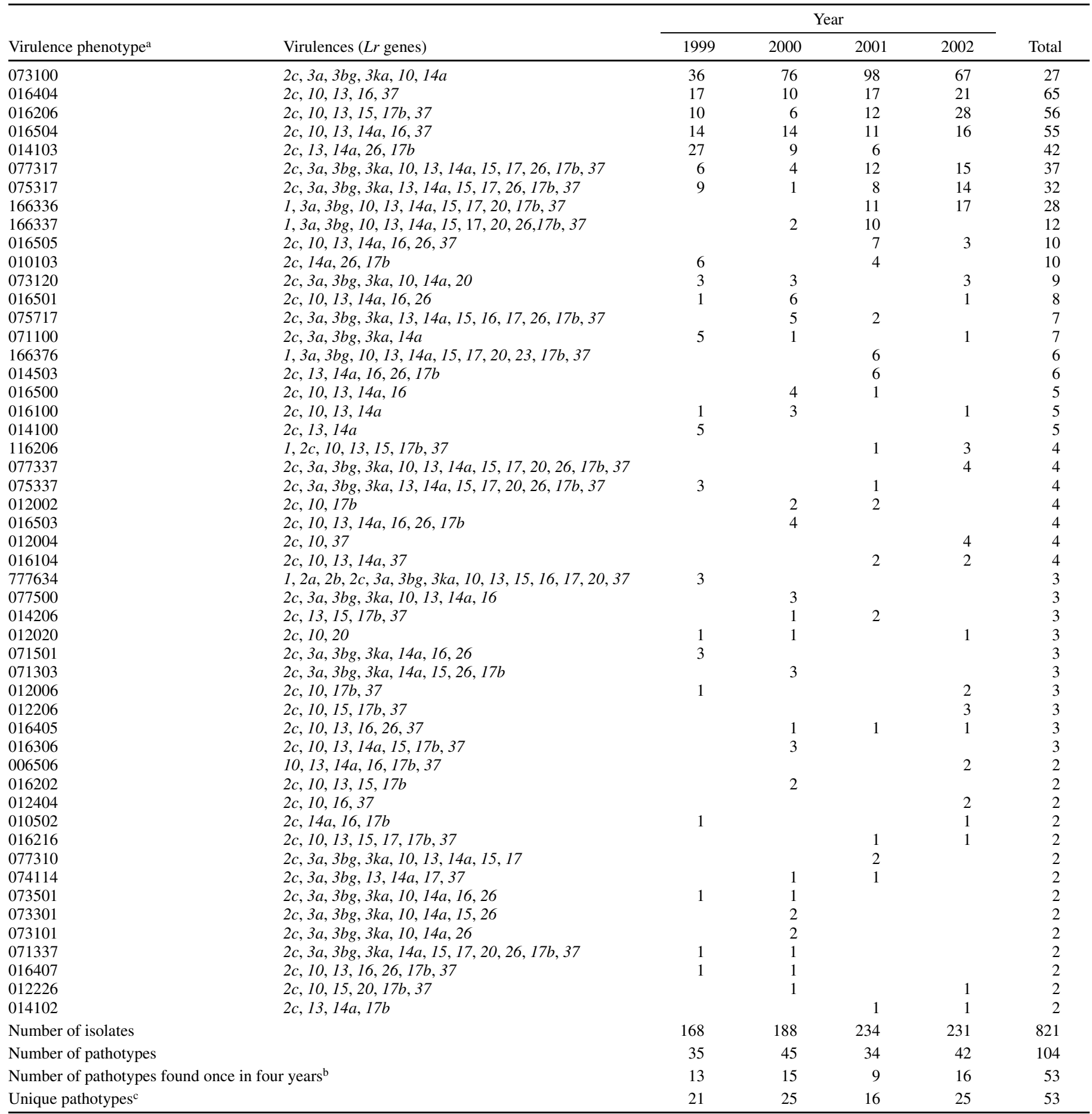

${ }^{a}$ Six-digit code based on an 18-Lr genes differential set (Thatcher lines Lr1, Lr2a, Lr2b, Lr2c, Lr3, Lr3bg, Lr3ka, Lr10, Lr13, Lr14a, Lr15, Lr16, Lr17, Lr20, Lr23, Lr26, the Australian cv. Harrier ( $\operatorname{rr} 17 b)$, and $\operatorname{Lr} 37$.

${ }^{\mathrm{b}}$ Pathotypes found only once in 4 years have been pooled in a group and their virulence formula is not given here.

${ }^{\mathrm{c}}$ Number of pathotypes found only once for each year. 
Diversity and evenness in $\mathrm{P}_{\mathrm{b}}$ were stable across the 4 years. The diversity in $\mathrm{P}_{\mathrm{b}}$, as measured by the Shannon index, ranged between 2.43 and 2.76 . These values were very similar to those observed in some epidemiological areas of the United States $(18,19)$. In the eastern and prairie areas of Canada in the period 1931-1987, the Shannon index was mostly between 1 and 2 and it dropped below 1 in the prairies after the introduction of resistant cultivars (14), but the use of only four differential lines resulted in lower diversity as compared with other studies using more differential lines. In Israel, with isolates derived from durum wheat and bread wheat and in an area where a high diversity could be expected because of the presence of indigenous wild Triticum and Aegilops spp. relatives, the Shannon index values were very close to those calculated in our study, ranging between 2.147 and 2.969 in 1994-1997 (21).

The Shannon index calculated for France in a previous study in 1995 (29) was lower than the values obtained here, ranging between 0.75 and 1.67 . In the 1995 study, sample sizes were smaller than in our study. The Shannon index underestimates diversity in small samples as compared with big samples (19). Although Park et al. (29) used 25 differentials while we used only 18, they did not include $\mathrm{Lrl3}$ and $\mathrm{LrlHa}$, the most frequent resistance genes (Table 7) in the French wheat host population. Using these resistance genes in our differential set may have permitted discrimination of more pathotypes. Although the differential set we used differed from that used by Park and Felsenstein (28) for a few lines, it is likely that the two predominant pathotypes 17 and 39 (28) found in Europe in 1995 were the same as pathotypes 014103 and 073100 in our study, respectively. On the other hand, pathotypes 3 and 6, common in France in the 1995 study, were not found in our study. Aerial spore trapping as used in the 1995 study has been shown to reflect mainly pathogen populations from fields bordering the sampling route (10). The spores trapped from pathotypes 3 and 6 might therefore, have come mainly from Sideral (LrI3 and LrI4a), the second most widely grown cultivar in these areas in 1995. The sharp decline in the cultivation of Sideral from 1998 and lack of a sample from it in the current study may explain why pathotypes 3 and 6 were not detected during the 1999-2002 period.

Comparison between durum wheat $\left(P_{d}\right)$ and bread wheat $\left(\mathbf{P}_{\mathbf{b}}\right)$. The first level of differentiation made in French wheat leaf rust populations was between isolates originating from durum and bread wheat. Although virulence frequencies (Table 5) could be biased because of the smaller size of the sample derived from $P_{d}$, the frequency of virulence on $L r 20$ was much higher on $\mathrm{P}_{\mathrm{d}}$ than on $\mathrm{P}_{\mathrm{b}}$, and the frequency of virulence on $\operatorname{Lr} 13, \mathrm{Lr} 14 \mathrm{a}$, and $\mathrm{Lrl6}$ was lower on $\mathrm{P}_{\mathrm{d}}$ than on $\mathrm{P}_{\mathrm{b}}$. Resistance gene $L r 20$ is infrequent in bread wheat cultivars (Table 7). Information about $L r$ resistance genes in the durum wheat cultivars is missing so we do not know if the high virulence frequency for $\operatorname{Lr} 20$ in $\mathrm{P}_{\mathrm{d}}$ results from selection by host. The most frequent pathotype on durum wheat, 012020, represented $47 \%$ of all pathotypes collected in 3 years for durum wheat, whereas it was only $0.3 \%$ of pathotypes collected in 4 years from bread wheat, which is not surprising given that 012020 did not have the virulences matching the resistance genes carried by the main bread wheat cultivars. Almost one-half of the pathotypes found on durum wheat were rare or not found at all on bread wheat. Thus, we concluded that leaf rust populations from durum and bread wheat were different as was shown in Morocco (6), Mexico (33), and international collections $(11,26)$. Pathotype 012062, found in 2001 in France (Table 5), appears to be the same as the new race $\mathrm{BBG} / \mathrm{BN}$ detected in 2001 on durum wheat in Mexico (34).

With the differential set used, we were able to detect differences between $\mathrm{P}_{\mathrm{d}}$ and $\mathrm{P}_{\mathrm{b}}$, thus, to conclude to a differential selection exerted by host species. A study of selection by host within $\mathrm{P}_{\mathrm{d}}$ would require the characterization of the resistance genes in the durum wheat cultivars, and the definition of a corresponding differential set. Moreover, it is possible that $P$. triticina and $P$. recondita occur on durum wheat in France since both species occur in the Mediterranean area, (Italy, Morocco, Spain, and Portugal) (2).

Diversity and distribution of pathotypes in the bread wheat leaf rust populations $\left(\mathbf{P}_{\mathbf{1}}\right.$ to $\left.\mathbf{P}_{\mathbf{5}}\right)$. Differences between the years could be found in diversity or evenness for some cultivars, but no year was characterized by a general increase or decrease in these two indexes. Diversity was similar in the two populations from susceptible cvs. Soissons $\left(\mathrm{P}_{1}\right)$ and Isengrain $\left(\mathrm{P}_{2}\right)$ in the 4 years, but it was lower than in the three populations from resistant cvs. Trémie $\left(\mathrm{P}_{3}\right)$, Apache $\left(\mathrm{P}_{4}\right)$, and Orvantis $\left(\mathrm{P}_{5}\right)$ in all years except 1999 where it was lower in $P_{3}$ than in $P_{1}$ and $P_{2}$. Since evenness was the same across the cultivars in 1999, the difference between $\mathrm{P}_{3}$ on one hand and $\mathrm{P}_{1}$ and $\mathrm{P}_{2}$ on the other hand in that year was due to a lower richness in $\mathrm{P}_{3}$. In the two following years, 2000 and 2001, the significant differences in diversity between susceptible and resistant cultivars were attributed to differences in

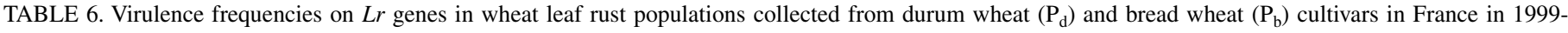
2002

\begin{tabular}{|c|c|c|c|c|c|c|c|}
\hline \multirow[b]{2}{*}{ Gene } & \multicolumn{2}{|c|}{1999} & \multicolumn{2}{|c|}{2000} & \multicolumn{2}{|c|}{2001} & \multirow{2}{*}{$\frac{2002^{\mathrm{a}}}{\text { Bread }}$} \\
\hline & Durum & Bread & Durum & Bread & Durum & Bread & \\
\hline Lrl & 0.16 & 0.02 & 0.00 & 0.03 & 0.00 & 0.13 & 0.10 \\
\hline $\operatorname{Lr} 2 a$ & 0.16 & 0.02 & 0.00 & 0.01 & 0.00 & 0.00 & 0.00 \\
\hline$L r 2 b$ & 0.16 & 0.02 & 0.00 & 0.01 & 0.00 & 0.00 & 0.00 \\
\hline $\operatorname{Lr} 2 c$ & 1.00 & 0.99 & 1.00 & 0.98 & 1.00 & 0.88 & 0.90 \\
\hline$L r 3 a$ & 0.47 & 0.44 & 0.38 & 0.57 & 0.17 & 0.66 & 0.54 \\
\hline Lr3bg & 0.47 & 0.44 & 0.38 & 0.57 & 0.17 & 0.66 & 0.54 \\
\hline Lr3ka & 0.47 & 0.44 & 0.38 & 0.56 & 0.17 & 0.53 & 0.46 \\
\hline Lr10 & 0.42 & 0.61 & 1.00 & 0.86 & 0.98 & 0.85 & 0.90 \\
\hline $\operatorname{Lr} 13^{\mathrm{b}}$ & 0.42 & 0.62 & 0.06 & 0.46 & 0.02 & 0.53 & 0.61 \\
\hline $\operatorname{Lr} 14 a^{\mathrm{b}}$ & 0.47 & 0.79 & 0.44 & 0.84 & 0.23 & 0.83 & 0.69 \\
\hline Lr15 & 0.47 & 0.22 & 0.00 & 0.19 & 0.02 & 0.31 & 0.40 \\
\hline $\operatorname{Lr} 16^{\mathrm{b}}$ & 0.05 & 0.26 & 0.19 & 0.29 & 0.00 & 0.20 & 0.21 \\
\hline Lr17 & 0.47 & 0.16 & 0.00 & 0.08 & 0.02 & 0.24 & 0.25 \\
\hline$L r 17 b$ & 0.58 & 0.39 & 0.06 & 0.27 & 0.21 & 0.39 & 0.44 \\
\hline $\operatorname{Lr} 20^{\mathrm{b}}$ & 0.74 & 0.08 & 0.44 & 0.05 & 0.83 & 0.13 & 0.12 \\
\hline $\operatorname{Lr} 23$ & 0.05 & 0.00 & 0.00 & 0.00 & 0.17 & 0.03 & 0.00 \\
\hline $\operatorname{Lr} 26$ & 0.58 & 0.36 & 0.00 & 0.26 & 0.02 & 0.25 & 0.19 \\
\hline Lr37 & 0.47 & 0.42 & 0.13 & 0.30 & 0.02 & 0.47 & 0.65 \\
\hline
\end{tabular}

a Durum leaf rust population was not studied in 2002.

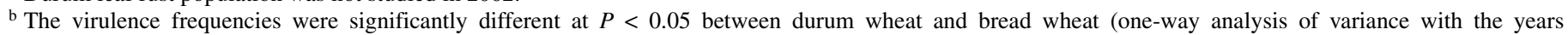
considered as replicates). 
evenness because evenness on the resistant cultivars was always higher than on the susceptible cultivars. The situation was similar in 2002, although differences in evenness between cultivars were not always significant. However, it is difficult to attribute the significant differences in diversity to the significant differences in richness because richness values for the different cultivars were very close, being between 11 and 14 . The small sample sizes of isolates collected from resistant cultivars could have been responsible for the lack of significance in some cases. Despite this, the general trend from these results was that diversity was higher on resistant cultivars than on susceptible cultivars, and this difference was due to evenness as it is shown clearly on Figure 1. Evenness on the susceptible cultivars was low because of the dominance of two pathotypes, 014103 and 073100 in 1999, and a single pathotype, 073100 in $2000-2002$, the frequency of which varied between 54 and $72 \%$. In contrast, in the Canadian prairie area in 1990, the Shannon index for resistant cultivars (pooled population sampled from 13 cultivars) was significantly lower than for susceptible cultivars (pooled population sampled from five cultivars), although the Rogers index and contingency table analysis showed that there was no significant difference between populations from resistant and susceptible cultivars (15).
The distribution of pathotypes was very similar on the two susceptible cvs. Soissons and Isengrain that carried the largely ineffective resistance gene $\operatorname{Lr} 14 a$, both of which also have a very similar genetic background. The populations $\mathrm{P}_{1}$ (Soissons) and $\mathrm{P}_{2}$ (Isengrain) were dominated by two pathotypes in 1999, after which one (014103) decreased in frequency and disappeared in 2002, while the other (073100) represented more than $70 \%$ of the population. The pathotype distribution was more balanced on the resistant cultivars as reflected by the evenness indexes being higher than on susceptible cultivars. A strong and rapid change in $\mathrm{P}_{3}$ was detected when two of the most frequent pathotypes, 016504 and 016206 , dropped in frequency in 2001 and were replaced by a group of three very similar pathotypes designated as 'group 166'. This group, absent in 1999, represented 6\% of $\mathrm{P}_{3}$ in 2000 and then $38 \%$ in 2001 . Group 166 comprised the most virulent pathotypes (virulent on 12 of 18 differential lines) and differed greatly from the other pathotypes common in France by avirulence on $L r 2 c$, virulence on Gatcher (results not presented here), combined virulence on Lrl, LrlO, and Lrl3, combined virulence on $L r 3 a$ and $L r 3 b g$, and avirulence on $L r 3 k a$. The most similar pathotypes described in the literature were pathotypes $\mathrm{MBD} / \mathrm{SM}$ and $\mathrm{MCD} / \mathrm{SM}$, dominant in CIMMYT nurseries in

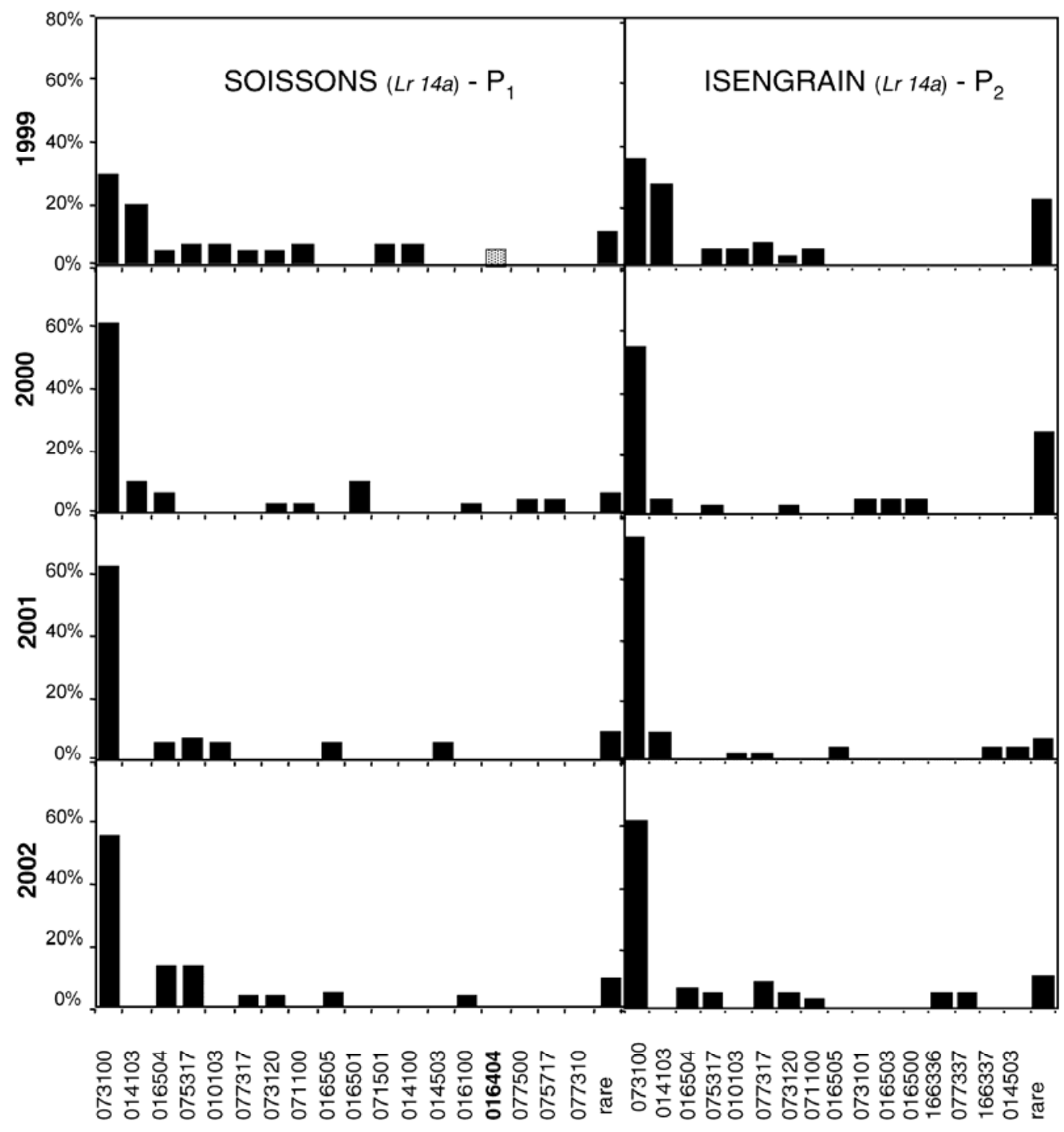

(continued on next page)

Fig. 1. Frequencies of Puccinia triticina pathotypes on five major bread wheat cultivars (populations $P_{1}$ to $P_{5}$ ) in France during 1999-2002. Black bars $=$ pathotype carrying the virulence gene(s) matching all the resistance gene(s) of the cultivar. Shaded bars and corresponding pathotype name in bold = pathotype lacking at least one of the virulence gene(s) matching resistance gene(s) of the cultivar. The pathotypes found only once at most for each year have been pooled in the category 'rare'. Susceptible cultivars are Soissons $\left(\mathrm{P}_{1}\right)$ and Isengrain $\left(\mathrm{P}_{2}\right)$. Resistant cultivars are Trémie $\left(\mathrm{P}_{3}\right)$, Apache $\left(\mathrm{P}_{4}\right)$, and Orvantis $\left(\mathrm{P}_{5}\right)$. 
1990 (33), but with the difference that these latter pathotypes were virulent on $L r 28$, whereas group 166 pathotypes were avirulent on $\operatorname{Lr} 28$ (results not presented here). Virulence for $L r 28$ is a characteristic of North American populations of $P$. triticina because the frequency of virulence for this gene is very high in these populations (33). Races with the same virulence as 'group 166' were found in North America starting in the mid-1990s. These races were found to have very distinct amplified fragment length polymorphism (AFLP) patterns compared with other races (17).

The isolation of pathotype 073100 , avirulent on $\mathrm{Lr} 13$, from three cultivars carrying this gene (Trémie, Apache, and Orvantis) was not unexpected because it was known that this resistance gene does not completely prevent sporulation by avirulent pathotypes. Although $98 \%$ of the wheat fields in France are sprayed with fungicide, inoculum is present every year as shown by epidemics occurring on any untreated plot. On a cultivar as susceptible as Soissons, infections can still be observed after treatments when environmental conditions are conducive. Infections can also be easily observed in newly planted commercial fields in the fall and it is likely that some inoculum survive on volunteers during the summer. The stability of the pathotype distribution on cv. Soissons over 4 years also suggested survival of local inoculum. The differences between pathotype distributions observed in populations from cvs. Soissons and Trémie suggested that a strong selection was exerted on the inoculum by the cultivar.

Distribution of pathotypes and resistance factors in the cultivars. In several cases, the distribution of some pathotypes on the different cultivars could not be explained by the selection exerted by specific host resistance genes only. Ten to eighteen pathotypes, although virulent on $\operatorname{Lr} 14 a$, and therefore, virulent on cvs. Soissons and Isengrain carrying only $L r 14 a$ and no adult plant resistance gene, occurred in $\mathrm{P}_{1}$ and $\mathrm{P}_{2}$ but remained at frequencies much lower than the dominant pathotype 073100. Several virulence gene combinations, including the most complex one, were found only on resistant cultivars even though these multivirulent pathotypes were primarily virulent on the susceptible cultivars and despite the fact that our samples were collected from small plot nurseries, where exchange of inoculum between plots is expected to be frequent. The two cultivars from which populations were similar (Soissons and Isengrain) had the same resistance gene and a similar genetic background. It is particularly surprising that pathotype 073100 remained at a high and stable frequency during the 4 years, whereas all other virulent pathoytpes either decreased in frequency (014103) or never increased in frequency in the population. Given that Soissons was a largely dominant cultivar in the period 1991-1999 and considering that

Fig. 1. (continued from preceding page)

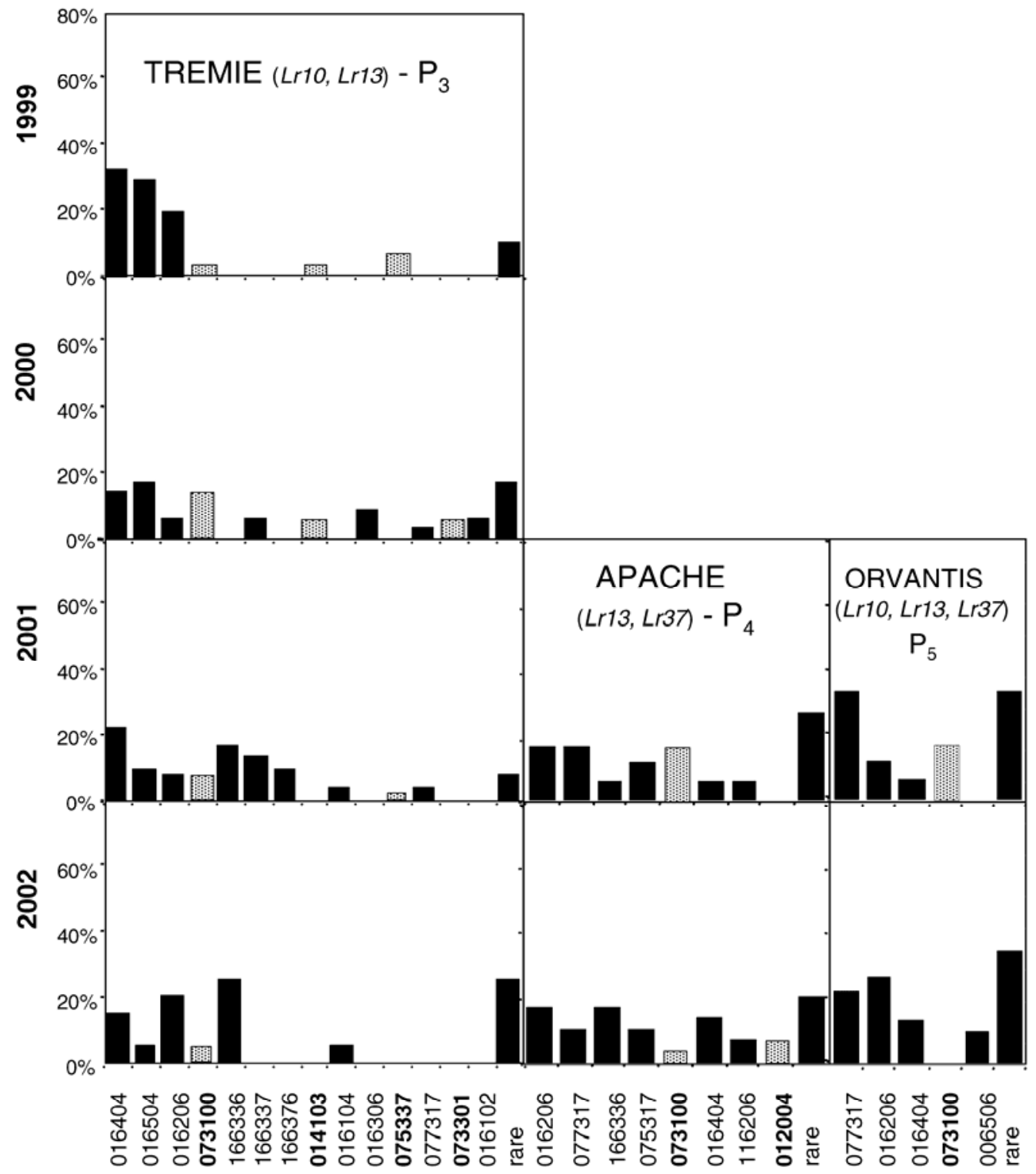


pathotype 073100 was not frequent on the other dominant cultivars (except on Isengrain, which has the same resistance gene and a genetic background close to that of Soissons), it is unlikely that the dominance of 073100 in the global population could be accounted for by another reason than a strong aggressiveness on cvs. Soissons and Isengrain. This hypothesis is reinforced by considering the transition between 1999, where 073100 coexisted with 014103 , and year 2000, where 073100 remained the only dominant pathotype. Although this has not been tested, this high frequency of 014103, virulent on Lr13 in 1999, might result from the development of epidemics on cv Thésée (Lr13) that was largely cultivated from 1988 to 1997 and on which 073100 is avirulent.

It appears then that leaf rust epidemics on the susceptible cultivars were mainly caused by a single pathotype (073100) despite the presence of a fairly large diversity of other virulent pathotypes in the global population, and this for several years. In this situation, the knowledge of the frequency and distribution of resistance genes in the host population and of the virulence combinations in the pathogen population is not sufficient to predict or explain the distribution and frequency of the pathotypes. When isolates of $P$. graminis f. sp. tritici, virulent on commonly grown cultivars, were found at very low frequencies (31), it was suggested by Alexander et al. (1) that negative associations between virulence and traits affecting spore survival and reproduction may be responsible. In our case, a converse hypothesis may be proposed, in which a higher aggressiveness of pathotype 073100 could lead to a strong dominance of this pathotype over other pathotypes virulent on Lr14a. A few population studies show that the dominance of a subpopulation (pathotype, clonal lineage) in a global population can be accounted for by differences in aggressiveness (24). This can sometimes be explained by a better adaptation to specific climatic conditions (13). This latter explanation is unlikely here, given the high frequency of 073100 over several consecutive years. Other studies have concluded that rust population structure is likely to be influenced by characters other than the interaction of host resistance genes and corresponding genes in the pathogen $(22,29)$. High levels of diversity maintained in North American wheat leaf rust populations indicate that selection for virulence to

TABLE 7. Mean percentage of wheat area planted during 1999-2002 with the different $L r$ genes postulated in the 35 most commonly grown cultivars

\begin{tabular}{lcc}
\hline Lr gene combination & Mean percentage of wheat area & No. of cultivars \\
\hline No gene & 4.3 & 3 \\
Lr10, Lr13 & 10.0 & 3 \\
Lr10, Lr13, Lr26 & 0.7 & 1 \\
Lr10, Lr13, Lr37 & 0.7 & 2 \\
Lr13 & 16.2 & 10 \\
Lr13, 20 & 1.0 & 1 \\
Lr13, Lr14a & 5.3 & 2 \\
Lr13, Lr26 & 2.5 & 1 \\
Lr13, Lr37 & 2.9 & 3 \\
Lr14a & 29.4 & 4 \\
Lr14a, Lr37 & 0.3 & 1 \\
Lr26 & 0.6 & 1 \\
Lr3a & 0.6 & 1 \\
Lr3a, Lr13 & 0.8 & 2 \\
Total & $75.3^{\mathrm{a}}$ & 35
\end{tabular}

Cumulative percentage of wheat area for each $L r$ gene Lr gene

$\begin{array}{lr}\text { Lr13 } & 40.1 \\ \text { Lr14a } & 35.1 \\ \text { Lr10 } & 11.3 \\ \text { No gene } & 4.3 \\ \text { Lr37 } & 4.0 \\ \text { Lr26 } & 3.2 \\ \text { Lr3a } & 1.4 \\ \text { Lr20 } & 1.0\end{array}$

a The total is not $100 \%$ because the minor cultivars are not included in this table. host resistance genes is effectively balanced by other selective forces (16).

Group 166, virulent on $\operatorname{LrlO}$ and $\operatorname{Lrl3}$, occurred on cvs. Trémie (Lr10 and Lr13) and Apache (Lr13 and Lr37) but not on cv. Orvantis ( $L r 10, L r 13$, and $L r 37)$. Thus again, interactions with a specific resistance gene(s) cannot explain the absence of this group on cv. Orvantis, unless cvs. Apache and Orvantis have unknown and different adult-plant resistance gene(s). Pathotype 077317, although virulent on $\mathrm{LrlO}$ and $\mathrm{Lr13}$, was absent or rare on cv. Trémie. For these populations, derived from resistant cultivars and where the structure observed could not be fully explained by interaction of known genes for resistance and avirulence, possible differences in aggressiveness may contribute to pathogen population composition, as for the dominance of 073100 on cvs. Soissons and Isengrain. However, unlike for the susceptible cultivars, it is not known here whether specific adultplant resistance is present in the resistant cultivars. For example, Bartos et al. (4) concluded that race frequency in the former Czechoslovakia could not be explained on the basis of host selection, but the study of Park et al. (29) showed that many cultivars registered there carried $\operatorname{Lr} 13$, a gene that had not been considered in their study. In France, unexplained differences between leaf rust populations from cvs. Soissons and Thésée in 1993-1995 (8) may well have been due to the presence of the resistance genes Lr14a in Soissons and Lrl3 in Thésée, as virulence for these genes was not monitored in these years.

In summary, $P$. triticina populations in France were diverse for virulence despite the presence of only a few specific resistance genes in host bread wheat cultivars. The potential occurrence of recombination, which could explain the observed diversity, still has to be tested. Populations were strongly differentiated between durum wheat and bread wheat cultivars and within bread wheat cultivars. Diversity was high on those that were resistant, mainly due to an evenness found to be higher for resistance as compared with susceptible cultivars. The population structure described in our study stresses the importance for sampling procedures to take into account the host cultivar for measuring the influence of selective factors on wheat leaf rust populations, as completely different virulence or pathotype frequencies could be obtained, depending on the host cultivars represented in the sample.

Last, we showed with a large-scale study that specific interactions in the leaf rust-wheat pathosystem were necessary but not sufficient to account for pathotype distribution and frequency on the cultivars. Other factors like aggressiveness, could account for the dominance of one or a few pathotypes on some cultivars over several years.

\section{ACKNOWLEDGMENTS}

We thank A.-C. Zippert for excellent technical assistance in collecting, isolating, maintaining, and testing cultures of Puccinia triticina. We gratefully acknowledge the French Wheat Breeders group 'Club des Cinq' for permitting collection of isolates on their field trial network and 'Arvalis Institut du Végétal' for their help in collecting samples.

\section{LITERATURE CITED}

1. Alexander, H. M., Groth, J. V., and Roelfs, A. P. 1985. Virulence changes in Uromyces appendiculatus after five asexual generations on a partially resistant cultivar of Phaseolus vulgaris. Phytopathology 75:449-453.

2. Anikster, Y., Bushnell, W. R., Eilam, T., Manisterski, J., and Roelfs, A. P. 1997. Puccinia recondita causing leaf rust on cultivated wheats, wild wheats, and rye. Can. J. Bot. 75:2082-2096.

3. Anonymous. 2004. Enquête sur les pratiques culturales en 2001. Agreste Chiffres et Données Agriculture 159:38. Ministère de l'Agriculture, de l'Alimentation, de la Pêche et des Affaires Rurales.

4. Bartos, P., Stuchlikova, E., and Hanusova, R. 1996. Adaptation of wheat rusts to the wheat cultivars in former Czechoslovakia. Euphytica 92:95-103.

5. Brown, J. K. M. 1998. Surveys of variation in pathogen populations and their application to disease control. Pages 73-102 in: The Epidemiology 
of Plant Diseases. D. Gareth Jones, ed. Kluwer Publishers, Dordrecht.

6. Ezzahiri, B., Diouri, S., and Roelfs, A. P. 1994. Pathogenicity of Puccinia recondita f. sp. tritici in Morocco during 1985, 1988, 1990, and 1992. Plant Dis. 78:407-410.

7. Gilmour, J. 1973. Octal notation for designating physiologic races of plant pathogens. Nature 242:620.

8. Goyeau, H., and de Vallavieille-Pope, C. 1996. Population structure and sampling of Puccinia recondita f. sp. tritici in France during 1993-1995. Page 136 in: 9th European and Mediterranean Cereal Rusts and Powdery Mildews Conference. G. H. J. Kema, R. E. Niks, and R. A. Daamen, eds. Lunteren, the Netherlands.

9. Grünwald, N. J., Goodwin, S. B., Milgroom, M. G., and Fry, W. E. 2003. Analysis of genotypic diversity data for populations of microorganisms. Phytopathology 93:738-746.

10. Hovmøller, M. S., Munk, L., and Østergård, H. 1995. Comparison of mobile and stationary spore-sampling techniques for estimating virulence frequencies in aerial barley powdery mildew populations. Plant Pathol. 44:829-837.

11. Huerta-Espino, J., and Roelfs, A. P. 1992. Leaf rust on durum wheats. Vortr. f. Pflanzenz. 24:100-102.

12. Johnston, C. O., Caldwell, R. M., Compton, L. E., and Browder, L. E. 1968. Physiologic races of Puccinia recondita f. sp. tritici in the United States from 1926 through 1960. U.S. Dep. Agric. Plant Dis. Rep. Tech. Bull. 1393.

13. Katsuya, K., and Green, G. J. 1967. Reproductive potentials of races $15 B$ and 56 of wheat stem rust. Can. J. Bot. 45:1077-1091.

14. Kolmer, J. A. 1991. Phenotypic diversity in two populations of Puccinia recondita f. sp. tritici in Canada during 1931-1987. Phytopathology 81:311-315.

15. Kolmer, J. A. 1992. Diversity of virulence phenotypes and effect of host sampling between and within populations of Puccinia recondita f. sp. tritici in Canada. Plant Dis. 76:618-621.

16. Kolmer, J. A. 1993. Selection in a heterogeneous population of Puccinia recondita f. sp. tritici. Phytopathology 83:909-914.

17. Kolmer, J. A. 2001. Molecular polymorphism and virulence phenotypes of the wheat leaf rust fungus Puccinia triticina in Canada. Can. J. Bot. 79:917-926.

18. Leonard, K. J., Roelfs, A. P., and Long, D. 1992. Diversity of virulence within and among populations of Puccinia recondita f. sp. tritici in different areas of the United States. Plant Dis. 76:500-504.

19. Long, D. L., Leonard, K. J., and Roberts, J. J. 1998. Virulence and diversity of wheat leaf rust in the United States in 1993 to 1995. Plant Dis. 82:1391-1400.

20. Long, D. L., Schafer, J. F., and Roelfs, A. P. 1985. Specific virulence of Puccinia recondita f. sp. tritici in the United States from 1978 through 1983. Plant Dis. 69: 343-347.

21. Manisterski, J., Eyal, Z., Ben-Yehuda, P., and Kosman, E. 2000. Comparative analysis of indices in the study of virulence diversity between and within populations of Puccinia recondita f. sp. tritici in Israel. Phytopathology 90:601-607.

22. Martens, J. W. 1985. Oat stem rust. Pages 103-129 in: The Cereal Rusts. A. P. Roelfs and W. R. Bushnell, eds. Vol. II, Academic Press, London.

23. Mesterhazy, A., Bartos, P., Goyeau, H., Niks, R. E., Csösz, M., Andersen, O., Casulli, F., Ittu, M., Jones, E., Manisterski, J., Manninger, K., Pasquini, M., Rubiales, D., Schachermayr, G., Strzembicka, A., Szunics, L., Todorova, M., Unger, O., Vanco, B., Vida, G., and Walther, U. 2000. European virulence survey for leaf rust in wheat. Agronomie 20:793-804.

24. Mundt, C. C., Nieva, L. P., Vera Cruz, C. M. 2002. Variation for aggressiveness within and between lineages of Xanthomonas oryzae pv. oryzae. Plant Pathol. 51:163-168.

25. Oerke, E. C. 1994. Estimated crop losses due to pathogens, animal pests and weeds-Estimated crop losses in wheat. Pages 179-275 in: Crop Production and Crop Protection. Estimated Losses in Major Food and Cash Crops. Elsevier, Amsterdam.

26. Ordonez, M. E., Kolmer, J. A., and Groth, J. A. 2004. Virulence specificities of world wide collections of Puccinia triticina from durum wheat. (Abstr.) Phytopathology 94(suppl):S79.

27. Park, R. F. 1996. Pathogenic specialisation of Puccinia recondita f. sp. tritici in Australia and New Zealand in 1990 and 1991. Aust. Plant Pathol. 25:12-17.

28. Park, R. F., and Felsenstein, F. G. 1998. Physiologic specialisation and pathotype distribution of Puccinia recondita in western Europe, 1995. Plant Pathol. 47:157-164.

29. Park, R. F., Goyeau, H., Felsenstein, F. G., Bartos, P., and Zeller, F. J. 2001. Regional phenotypic diversity of Puccinia triticina and wheat host resistance in western Europe, 1995. Euphytica 122:113-127.

30. Peterson, R. F., Campbell, A. B., and Hannah, A. E. 1948. A diagrammatic scale for estimating rust intensity of leaves and stems of cereals. Can. J. Res. Sect. C 26:496-500.

31. Roelfs, A. P., Long, D. L., and Casper, D. H. 1983. Races of Puccinia graminis f. sp. tritici in the United States and Mexico in 1981. Plant Dis. 67:82-84.

32. Singh, D., Park, R. F., and McIntosh, R. A. 2001. Inheritance of seedling and adult plant resistance to leaf rust of selected Australian spring and English winter wheat varieties. Plant Breed. 120:503-507.

33. Singh, R. P. 1991. Pathogenicity variations of Puccinia recondita f. sp. tritici and $P$. graminis f. sp. tritici in wheat-growing areas of Mexico during 1988 and 1989. Plant Dis. 75:790-794.

34. Singh, R. P., Huerta-Espino, J., Pfeiffer, W., and Figueroa-Lopez, P. 2004. Occurrence and impact of a new leaf rust race on durum wheat in northeastern Mexico from 2001 to 2003. Plant Dis. 88:703-708.

35. Stakman, E. C., Stewart, D. M., and Loegering, W. Q. 1962. Pages 1-53 in: Identification of physiologic races of Puccinia graminis var. tritici. U.S. Agric. Res. Serv. ARS E617.

36. Wolfe, M., and Knott, D. R. 1982. Populations of plant pathogens: Some constraints on analysis of variation in pathogenicity. Plant Pathol. 31:79-90. 